\title{
RIBA DALAM PERSPEKTIF HADĪS NABI SAW
}

\author{
Muhammad Sabir*
}

\section{PENDAHULUAN}

\section{A. Latar Belakang Masalah}

Hadīs Nabi Saw merupakan prima source ajaran Islam setelah alQuran. Jika dilihat dari segi dalalah, al-Quran sama dengan hadīs

Nabi Saw: keduanya ada yang qath'i al-dalalah dan ada juga yang zanni al-dalalah. Hanya saja al-Quran pada umumnya bersifat global, memuat makna yang padat. Sedangkan hadiss pada umumnya bersifat terperinci, yang salah satu fungsinya terhadap al-Quran adalah bayan al-Tafsir atau bayan al-tafsil. Dan juga kalimat yang dipergunakan pada matan hadīs ada yang mujmal, musykīl, khäfi,

* Dosen Mata Kuliah Hadis di Universitas Islam Negeri (UIN) Alauddin Makassar dan sekarang tengah menempuh program $\mathrm{S} 3$ di universitas yang sama.

Kata Qath' $i$ dalam berbagai literatur disamakan dengan kata daruri, absolut dan mutlak. Qath'i al-dalalah adalah nash yang merujuk pada satu pengertian tertentu dan tidak ada kemungkinan ta'wil ataupun peluang untuk memberikan interpretasi lain, pengertian ini pula disamakan dengan istilah muhkam. Sedangkan kata zanni al-dalalah disamakan dengan kata nazari, relatif dan nisbi, maka zanni al-dalalah adalah nash yang memerlukan interpretasi se- hingga membuka "peluang" para ulama dan pemikir lain berbeda pendapat, diistilahkan dengan mutasyabih. Abdul Wahab al-Khallaf, Ilmu Ushul al-Fiqh, (Jakarta: Majelis al-'Ala Indonesia li al-Da'wah al-Islamiyah, 1972), h. 34-35.

M.Quraish Shihab, Membumikan al-Quran; Fungsi dan Peran Wahyu dalam Kehidupan Masyarakat, (Cet. XII; Bandung: Mizan, 1996), h. 123-124. Mujmal artinya kata yang hanya dapat dipahami maknanya dengan penjelasan kata yang lain karena terdapat kemiripan makna. Arifuddin Ahmad, Paradigma baru Memahami Hadis Nabi, (Cet. I: Jakarta: Renaisan, 2005), h. 2. Al-Sayȳ̄d Syarīf bin Muhammad bin Ali al-Sayyīd al-Zain Abu Al-Hasan al-Husaini alJurjani al-Hanafi, al-Ta'rifat, (Mesir: Mustafa al-Babi' al-Halabi' wa Syurakahu 1938), h. 180.

Musykil berarti kata yang tidak dapat dipahami maknanya kecuali dengan mela- kukan penelitian yang lebih mendalam. Sayyīd Syrīf, ibid., h. 161.

Khafi berarti kata yang mengandung makna implisit sebab menggunakan kata yang bukan makna aslinya. ibid. 
dan atau mutasyābih.

Hadīs Nabi saw seperti dalam penjelasan al-Quran merupakan sumber kedua setelah al-Quran. Penjelasan tersebut adalah suatu keharusan-untuk tidak menyebutkan suatu kewajiban-bagi setiap Muslim untuk menjalankan dan memahami ajaran Islam secara benar dan tepat, dan tentu saja merujuk kepada kedua sumber tersebut.

Sebagai prima source ajaran Islam, tentu saja hadīs berbeda dengan al-Quran. Jika periwayatan al-Quran tidak pernah dipermasalahkan oleh umat Islam karena dalam sejarah kodifikasinya dan seluruh ayat yang terhimpun dalam mushaf tidak pernah mengalami sedikit pun pergeseran dan perubahan, baik pada zaman Nabi maupun sesudahnya, bahkan sampai sekarang ini, maka pada hadīs Nabi Saw yang diteliti dan dikaji tidak hanya kandungan dan aplikasinya, melainkan

Kalangan ahli fiqh berpendapat bahwa mutasyabih berarti suatu kata yang tidak mencerminkan makna yang asli, baik dari segi lafal, makna, maupun mak-na dan lafal sekiligus. Arifuddin Ahmad, ibid.

Lihat, QS. Al-Hasyr (59): 7; QS. Ali Imran (3): 32; QS. Al-Nisa' (4): 80, dan QS. Al-Ahzab (33): 21. Menurut petunjuk ayat ini menjelas bahwa al-Quran adalah the first source ajaran Islam dan hadis Nabi adalah the second source. Muhammadiyah Amin, Menembus Laitul Qadar: Perdebatan Interpertasi Ha-dis Tekstual dan Kontekstual, (Cet. I; Makassar: Melania Press, 2004), h.1. M. Syuhudi Ismail, Kaedah Kesahehan Sanad hadīs (Telaah) Kritis dan Tinjauan dengan Pendekatan Ilmu Sejarah), (Jakarta: Bulan Bintang, 1988), h. 85-86.

Hadis memiliki tiga fungsi penting, yaitu:

1. Sebagai pengukuhan dari hukum-hukum yang telah disebutkan Allah SWT di dalam al-Quran.

2. Sebagai penjelas dari isi al-Quran, karena ungkapan al-Quran masih bersifat global, seperti salat tidak dijelaskan tata cara dan rukunnya, dan nanti hadīs yang menjelaskannya.

3. Ada beberapa hukum yang tidak dijelaskan di dalam al-Quran dan nanti dijelaskan di dalam hadīs seperti hukumnya seorang perempuan tidak boleh dimadukan dengan bibinya. Harun Nasution, et. al., Ensiklopedi Islam Indonesia, (Jakarta: Djambatan, 1992), h. 272.

Pendapat Syuhudi terhadap latar belakang pentingnya penelitian hadis adalah:

1. Hadīs Nabi sebagai salah satu sumber ajaran Islam.

2. Tidak seluruh hadis tertulis pada zaman Nabi.

3. Telah timbul berbagai pemalsuan hadīs.

4. Proses penghimpunan hadīs memakan waktu yang lama. 
juga periwayatannya. ${ }^{10}$

Posisi hadīs yang sangat esensial dalam memahami ajaran Islam ini mengidentifikasi keberadaan, status, dan makna yang dimaksud pada setiap hadīs Nabi Saw itu sendiri sehingga, menjadi perhatian serius

oleh para ulama Muhaddisun. Perhatian ini sejak Nabi Saw masih hi- dup sampai periode al-Khulafa al-Rasyidun, bahkan lebih serius lagi pada masa tabî̀'în dan tabî̀'în-tabî'ìn.

Keseriusan mereka, karena terdapat kesulitan mengamalkan suatu hadīs yang disebabkan kesulitan dalam memahami kandungannya, maka pemahaman mengenai kandungan hadīs adalah "wajib" diperlukan. Sebab, fungsi Muhammad Saw sebagai Rasul atau pemimpin umat tidak terlepas dari konteks beliau sebagai manusia biasa dalam hidup keseharian (QS. Al-Kahfi: 110) dan setiap Nabi mengeluarkan pernyataan tidak terlepas kapan dan di mana konteks kehidupan Nabi Saw yang diucapkan atau dilakukannya. Untuk itu, pemahaman hadīs secara kontekstual menjadi sangat penting dalam mencapai pemahaman yang utuh dan runtut. Sehingga dengan demikian materi pemahaman tidak hanya secara tekstual, melainkan perlu dipahami secara kontekstual, baik yang bersifat universal, temporal maupun lokal.

Sebagai contoh yang penulis "angkat" dalam tulisan ini adalah persoalan larangan riba di dalam hadīs yang tertuju kepada bentuk riba' fadhl dan riba 'nāsiah yakni riba' yang dilakukan dalam bentuk tunai namun saling melebihkan atau barang atau benda yang serupa tetapi dengan selisih waktu salah satu dari barang yang ditukarkan. Sedangkan yang tercantum dalam al-Quran ${ }^{11}$ adalah larangan hanya

5. Jumlah kitab hadīs yang banyak dengan penyusunan yang beragam.

6. Telah terjadi periwayatan secara makna. M. Syuhudi Ismail, Metodologi Penelitian Hadīs Nabi, (Jakarta: Bulan Bintang 1992), h. 7-20.

10 M. Syuhudi Ismail, Dampak Penyebaran Hadīs Palsu dan Manfaat Pengetahuan: Sebab Hajat Turun dan Sebab Hadīs Terjadi bagi Muballig dan Pendidik, (Ujung Pandang: Berkah, 1989), h. 12.

11 QS. Al-Baqarah (2): 175, 176, 178, dan 179. Pada ayat-ayat ini, diterangkan bahwa perbuatan riba sangat tercela dan sama sekali tidak mendatangkan man- faat bagi pelakunya, dan bagi orang-orang yang melakukan kemudian mereka yang tidak mau berhenti maka, mereka berperang dengan Allah dan Rasul-Nya. 
dalam bentuk riba' nāsiah saja. ${ }^{12}$ Sementara pertukaran harta dengan harta lain, baik untuk dimiliki maupun dikuasai, hukumnya boleh, berdasarkan firman Allah (QS. Al-Baqarah: 2): Adapun riba dalam bentuk yang lain tidak dirinci oleh al-Quran. Di sinilah hadīs Nabi Saw menjelaskan lebih detail dengan melihat larangan riba itu sendiri.

Dengan melihat larangan riba, pada dasarnya terdapat kesesuaian sebagaimana halnya hukum khamar yakni ditetapkan secara berangsur-angsur. Larangan riba dalam Islam melalui empat tahap: ${ }^{13}$

1. Riba yang dimaksud untuk menambah harta itu tidaklah menam- bah di sisi Allah. ${ }^{14}$

2. Orang-orang Yahudi dilarang melakukan riba, tetapi larangan itu dilanggar oleh mereka sehingga mereka dimurkai Allah, dan diharamkan kepada mereka sesuatu yang telah pernah dihalalkan kepada mereka sebagai akibat pelanggaran yang mereka lakukan. ${ }^{15}$

3. Turun ayat yang melarang riba berlipat ganda. ${ }^{16}$

4. Larangan sisa-sisa riba yang masih ada. ${ }^{17}$ Dengan larangan yang bertahap-tahap ini tampak bahwa dalam menerapkan hukum Is- lam ditempuh tadrij (berangsur-angsur). ${ }^{18}$

Pembahasan ini penting karena dari dulu masalah tersebut telah menjadi perdebatan hangat di kalangan ulama dan cendekiawan Muslim. Di antara mereka ada yang mengharamkan, ada yang meng- anggapnya syubhat, dan ada pula yang menganggapnya mubah. Perbe- daan opini ini disebabkan oleh perbedaan sudut pendekatan masing-masing terhadap pelarangan riba.

12 Abu Husain Muslim bin al-Hajjaj al-Naisaburī, SahihMuslim, Jilid III, (t.tp: Mustafa al-Ba'bī al-Halabī, t.th.), h. 765.

13 Jalāl al-Dīn Abd. al-Rahmān Al-Suyūtiy, Lubāb al-Nuqūl fì Asbāb al-Nuzūl diterjemahkan oleh K. H. Q. Shaleh, et all, Asbabun Nuzul; Latar Belakang His- toris Turunnya Ayat-ayat al-Quran, (Bandung: Diponegoro, 1975), h. 83-84, 101, 160.

14 QS. Al-Rūm (30): 39.

15 QS. Al-Nisā (4): 160-161.

16 QS. Ali Imrān (3): 130.

17 QS. Al-Baqarah (2): 278-279.

18 H. Chuzaimah T. Yanggo dan H.A. Hafiz Anshary (ed), Problematika Hukum Islam Kontemporer, (Jakarta: LSIK, 1999), h. 36-37. 
Berdasarkan latar belakang yang penulis uraikan, maka yang men- jadi masalah pokok pembahasan adalah:

1. Bagaimana kualitas hadīs yang berkenaan dalam bentuk riba?

2. Bagaimana pendapat para ulama terhadap hadīs riba?

Hadīs yang terkait dengan pembahasan riba relatif banyak dan ber- ulang-ulang, dan setiap hadīs tidak menyebutkan jenis dan bentuk benda yang diribakan, maka tulisan ini hanya membatasi pada sejumlah hadīs yang dianggap dapat mewakili seluruh hadīs tentang riba baik dalam bentuk larangan, nāsiah maupun fadhl, sekaligus melihat pendapat para ulama masa lalu dan sekarang.'

Untuk menghindari terjadinya interpretasi yang keliru, penulis sa- ngat memandang urgen untuk menjelaskan beberapa istilah yang pen- ting dalam tulisan ini.

Kata riba secara etimologi adalah al-ziyādah, artinya tambahan dan dalam Maqāyisal-Lugah dikatakan rabā izā zāda wa 'alā. ${ }^{19}$ Kata riba adalah bentuk masdar dari kata ربايدربي_رب yang mempunyai beb- erapa makna, yakni "tambahan, tumbuh dan tinggi", ${ }^{20}$ tambahan atau kelebihan. ${ }^{21}$ Secara terminologi, riba adalah:



Riba adalah tambahan terhadap modal, tetapi dalam istilah hukum Is- lam, riba diartikan sebagai tambahan dengan kriteria tertentu.

Dalam Kamus Besar Bahasa Indonesia, kata riba diartikan sebagai pelepas uang, lintah darat, bunga uang dan rente. ${ }^{23}$ Menurut syara',

19 Abū Hasan Ibn Fāris Ibn Zakariyah, Mu'jam Maqāyis fi al-Lughah, jilid III, (t.t.: Mustāfa al-Bāby al-ㅌalaby, 1391 H./1971 M.), h. 25.

20 Abu Husain bin Fa'ris Zakariyah, Mu'jam Maqayis al-Lugah, (Cet.VII; [t.tp.]: al-Ba'bī al-Halabī, [t.th.]), h. 587. Bandingkan dengan A.W. Munawwir, Kamus Al-Munawwair Arab Indonesia lengkap, (Cet. II; Surabaya: Pustaka Progressif, 2002), h. 469.

21 Wahbah Zuhaili, Al-Figh al-Islamiyah Wa Adillatuh, juz IV, (Suria: Dar alFikr, 1989), h.636.

22 Al-Jurjāni, al-Ta'rîfāt, (Mesir: Musthāfa al-Bābi al-Halabi, 1978), h. 97.

23 Departemen Pendidikan dan Kebudayaan R.I., Kamus Besar Bahasa Indonesia, (Cet. III; Jakarta: Balai Pustaka, 1994), h. 840. 
kata riba bermakna tambahan yang disyaratkan pergantiannya kepada seseorang dalam bentuk transaksi jual beli. Dan juga adalah perolehan harta dengan harta lain dengan saling melebihkan antara satu dengan yang lain. ${ }^{24}$ Ulama fikih membagi kepada dua macam, yaitu riba' fadhl dan riba' nasi'ah. ${ }^{25}$ Ulama fikih telah sepakat mengharamkan riba' fadhl pada bermacam-macam benda yang tersebut dalam hadīs, yaitu emas, perak, anggur, gandum, kurma, dan garam. Tetapi mereka berbeda pendapat pada benda-benda selainnya.

Adapun kata hadīs berasal dari bahasa Arab, yakni al-hadīs jamaknya al-hadīs, al-hidsan dan al-hudsan. ${ }^{26}$ Secara etimologis hadīs mempunyai beberapa pengertian di antaranya: (1) al-hadīs: yang baru lawannya al-qadim yang lama, (2) al-khabar: khabar atau berita. Menurut ulama hadīs bahwa yang dimaksud hadīs adalah segala ucapan, perbuatan, taqrīr, dan hal-ihwal yang berasal dari Nabi Muhammad Saw. ${ }^{27}$ Dengan demikian, menurut penulis, yang dimaksud dengan hadīs adalah semua keadaan, perilaku dan ak- tivitas hidup Nabi Muhammad Saw. baik langsung maupun tidak langsung.

\section{A. Bagaimana kualitas hadīs yang berkenaan dalam bentuk pela- rangan riba}

\section{Hadīs tentang Larangan Riba, tentang Pemakan, Pemberi Makan, Juru Tulis, dan Saksi.}

Secara detail untuk melihat asal-usul hadīs, seluruh riwayat dan ada tidaknya syahid dan mutâbi' pada hadīs yang diteliti, maka perlu dilakukan takhrij al-hadīs. ${ }^{28}$ Metode takhrij yang ditempuh adalah

24 Taqiyuddin al-Nabhani, Al-Nizam al-Ijtihadiy Fi al-Islam, diterjemahkan oleh Masgfur Wachid dengan judul Membangun Sistem Ekonomi Alternatif: Perspektif Islam, (Surabaya: Risalah Gusti, 1996), h. 289.

25 Riba Fadhl adalah kelebihan pada salah satu harta sejenis yang diperjualbelikan dengan timbangan atau ukuran tertentu, sedangkan riba nasi'ah adalah kelebihan atas piutang yang diberikan orang yang berutang kepada pemilik modal ketika jatuh tempo. Wahbah Zuhaili, op.cit., h. 671-672.

26 M. Syuhudi Imail, Kaedah Kesahihan Hadis, op. cit., h. 40.

27 Ibid.

28 M. Syuhudi Ismail, Metodologi Penelitian Hadis Nabi, op.cit.,h. 43. 
metode $t$ a $k h r \hat{\imath} j$ bi al-lafzi, ${ }^{29}$ dengan lafaz الذهب maka, didapatkan informasi sebagai berikut:

$$
\begin{aligned}
& \text { 41, 44, } 46 \\
& \text { 1=24, 35, 45. }{ }^{30}
\end{aligned}
$$

Selanjutnya, penulis juga menelusuri lewat lafaz الو رق maka, didapatkan data sebagai berikut:



ط: عويب =38. 50, 43, 44, 47.45. 31 , 35, 24=1

Penulis menganalisis matan had̄̄s ini berdasarkan kaidah yang dikemukakan oleh M. Syuhudi Ismail, dan dapat dikategorikan sebagai hadīs yang memiliki redaksi kalimat yang teratur (tidak syaz) dan mengacu kepada nash yang lebih kuat yakni al-Quran, dan hadīs ini, jika dilihat dari segi matan, maka hadīs ini tidak terdapat syaz dan illat. Oleh karena itu, matan hadīs yang dimaksud dianggap sahīh jika dibuktikan dengan menelusuri redaksi (matan) yang dipergunakan oleh mukharīj seperti imam Bukharī sebagai berikut:



29 Abû Muhammad al-Mahdi, ${ }^{\circ}$ Urq Takhrij hadis Rasul Allah Saw, diterjemahkan oleh H.S.Aqil Husain Munawar dengan judul Metode Takhrij Hadis, (Semarang: Dina Utama, t.th), h. 60.

30 Arnold John Wensinck, Concordance Et Indices De La Tradition Musulmanne, diterjemahkan oleh Mu¥ammad Fuad Abd.al-Baqiy dengan judul Al-Mu'jam al-Mufahras Li Alfasi al-hadis al-Nabawiy, Juz II, (Leiden: E.J.Brill, 1936), h.191.

31 Imam al-Hafiz Abu Daud Sulaiman al-Asy-at bin Ishaq al-Azdī al-Jastan̄̄, Su- 
Telah menceritakan kepada kami Hajjaj bin Minhal telah menceritakan kepada kami Syu'bah berkata, telah mengabarkan kepada saya 'Aun bin Abu Juhaifah berkata: Aku melihat Bapakku membeli tukang bekam lalu memerintahkan untuk menghancurkan alat-alat bekamnya. Kemudian aku tanyakan masalah itu. Lalu Bapakku berkata: "Rasulullah shallallahu 'alaihi wasallam telah melarang harga (uang hasil jual beli) darah, anjing, memeras budak wanita dan melarang orang yang membuat tato dan yang minta ditato dan pemakan riba dan yang me- minjamkan riba, serta melaknat pembuat patung”.

Hajjaj bin al-Minhal dinilai oleh ulama seperti Ahmad bin Hanbal, sebagai Tsiqah; Abu Hatim mengatakan bahwa ia Tsiqah Fadil; An Nasa'i mengatakan bahwa ia Tsiqah; Ibnu Hibban menyebutnya 'ats tsiqaat; Ibnu Hajar al-'Asqalani mengatakan bahwa ia adalah Tsiqah Fadil.

Syu'bah bin Al Hajjaj bin al-Warad dari kalangan Tabi'ut Tabi'in, Wafat pada $160 \mathrm{H}$. Para ulama menilainya seperti al-'Ajli mengatakan ia adalah tsiqah tsabat; Ibnu Sa'd menyebutnya tsiqah ma'mun; Abu Daud mengatakan bahwa tak ada seorang pun yang lebih baik haditsnya daripadanya; Ats Tsauri mengatakan ia adalah amirul mukminin fil hadits; Ibnu Hajar Al-Atsqalani mengatakan bahwa ia adalah tsiqh hafidz; adz-Dzahabi mengatakan ia adalah tsabat hujjah.

Aun bin Abu Juhaifah Wahab bin 'Abdullah berasal dari kalangan tabi'in, dan wafat 116 H. Para ulama semisal Abu Hatim mengatakan bahwa ia tsiqah; Yahya bin Ma'in mengatakan bahwa ia tsiqah; AnNasa'i juga mengatakan bahwa ia tsiqah; Ibnu Hibban menyebutnya tsiqah; Ibnu Hajar al-Asqalani juga mengatakan bahwa ia tsiqah, AdzDzahabi mengatakan bahwa mereka mentsiqahkannya.

Wahab bin Abdullah berasal dari kalangan sahabat, wafat $74 \mathrm{H}$.

nan Abu Daud, Jilid III (t.tp: Al-Maktabah al-Ba'bī al-Halabī, 1381 H/1952M), h. 627. Hadis semakna terdapat pula pada Abd Rahman bin Syaibah, Sunan alNasa'-ī, Juz VII (Mesir: Mustafa al-Ba'bī al-Halabī, t.th.), h. 210. Ahmad bin Hanbal, Musnad Ahmad bin Hanbal, Juz II, (Bayrut: Da'r al-Fikr, t.th.), h. 83. Muhammad bin Yasir al- Qazwin̄, Sunan Ibn Majah, Juz II (Bayrut: Da'r al-Fikr, [t.th.]), h. 764. A.J. Wensick dan J.P. Mensing, Mu'jam Mufahras lī Alfa'z alHadīs al-Nabawī, Juz II, (London: A.Briel Leiden, 1943), h. 216-217. 
Tak ada komentar dari ulama, karena ia sahabat Nabi. ${ }^{32}$

Dari hadīs di atas dipahami bahwa riba yang dimaksudkan adalah riba' fadhl yang dilarang dalam rangka menghindari riba' nasi'ah. Dalam hadīs lain ditemukan lagi pengharaman untuk enam jenis ba- rang dalam kaitannya dengan riba, yaitu emas dan perak. Hadīs yang dimaksud diriwayatkan oleh al-Bukhāri sebagai berikut:

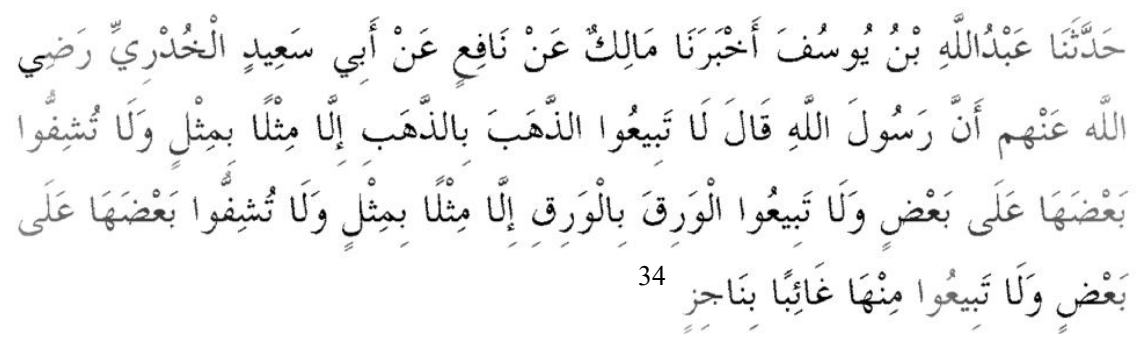

'Abdullāh bin Yūsuf menceritakan kepada kami, Mālik memberitakan kepada kami, dari Nāfi', dari Abū Sa'ìd al-Khudriy ra bahwa Rasulullah Saw bersabda: Kalian jangan menjual emas dengan (bayar) emas, kecuali sama-sama timbangan beratnya, dan jangan melebihkan yang satu dari yang lain. Jangan pula menjual perak dengan (bayar) perak kecuali sama-sama berat timbangannya, dan jangan melebihkan satu dari yang lain, dan jangan menjual yang tempo dengan yang (bayar) tunai (kontan).

Secara tekstual, hadīs ini dapat dikategorikan sebagai hadis riba. Karena ada barang yang sejenis tidak sama dan harus sepadan. Dua jenis benda yang tertera pada hadīs di atas, yakni emas dan perak sebagai standar muamalah dan pertukaran. Oleh sebab itu, pengharaman emas dan perak dalam muamalah dan pertukaran semata-mata karena nilai tukarnya tidak sama dalam transaksi harga.

Dari penelusuran penulisan dalam kutub al-tis'ah tentang hadīs larangan riba, maka penulis mendapati berbagai redaksi yang berbeda antara satu mukharij dengan mukharij lainnya terhadap matan hadīs riba, tapi pada dasarnya sama, yaitu tidak dibenarkannya

32 Lebih lengkapnya lihat A.J. Wensick dan J.P. Mensing, Mu'jam Mufahras lī Alfa'z al-Hadīs al-Nabawī, Juz VIII.

33 Abū 'Abdullāh ibn al-Mughīrah al-Bardzibat al-Bukhāri, Shahīh Bukhāri dalam CD. Rom al-Hadīś al-Syarīfah, Kitāb al-Buyū', hadis ke-2031. 
adanya penambahan. Antara lain al-Bukharī mentakhrīj dengan

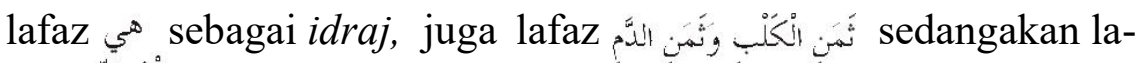
faz

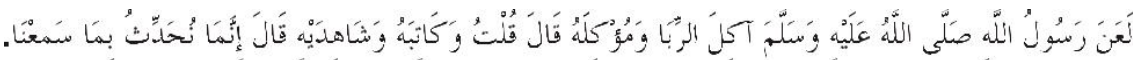
Adápun pada lafáz hadīs ḱedua terdapát ziyadah yaitu lafaz

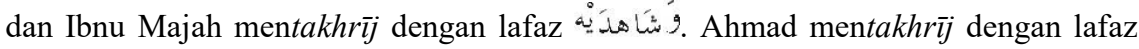

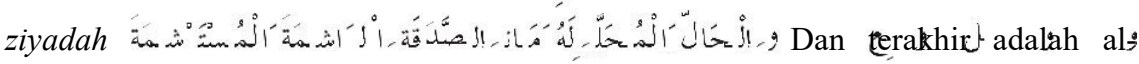
Darimī yang mentakhrīj hanya dengan lafaz

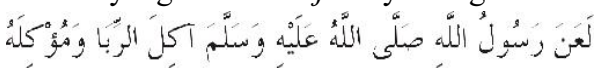

Dalam kaitan ini al-Nawawī mengatakan maksud dengan laknat Allah ialah perbuatan itu dinilai haram bagi mereka yang melibatkan diri dalam muamalah riba dan termasuk perbuatan yang batil dalam konteks syariah. ${ }^{34}$ Walau demikian, perubahan redaksi tidaklah mengubah makna yang dimaksud oleh hadīs tersebut. Seperti diketahui, makna yang dituju oleh hadīs adalah larangan tentang riba.

Redaksi atau matan hadīs tentang riba' nasi'ah, semua mukharrīj (kutub al-tis'ah) ternyata memakai redaksi yang tidak berbeda yaitu:

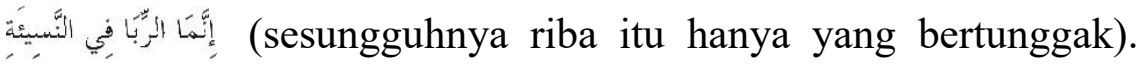
Al-Tirmizī sendiri memasukkan lafaz ini ke dalam lafaz hadīs

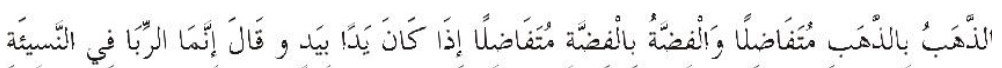

Meski demikian tidak mengubah makna hadīs dimaksud. Dengan demikian lafaz-lafaz hadīs di atas nyatanya tidak bertentangan antara satu dengan yang lain sehingga hadīs dimaksud dapat dinyatakan bebas dari syadz.

Hadīs tentang riba' fadal ini para mukharrīj mulai dari al-Bukharī, Muslim, Abu Dawud, Nasa'’̄i, Tirmidzī, Ahmad, Ibnu Majah serta Malik mencantumkan delapan jenis dari makanan, perhiasan, buahbuahan, uang, dan lauk-pauk. Benda-benda itu tidak dapat diperjualbelikan kecuali dalam takaran, timbangan, ukuran, dan jenis yang sama juga harus taransaksinya secara tunai. Al-Bukharī misalnya mentakhrïj dengan memakai lafaz s.s gs s. Adapun hadīs berikutnya memakai lafaz سو اء؟بو اء_مثلابمثل, lafaz ini pun dipakai oleh mukharrij

34 Ahmad Zakariyah al-Qanad al-Halawiy, Al-Muwaththa' wa Jazu al-Masalik (Cet. III; t.tp. Dar al-Fikr, 1980), h. 26. 
yang lainnya kemudian ditambah dengan lafaz يدابديد, Muslim men-

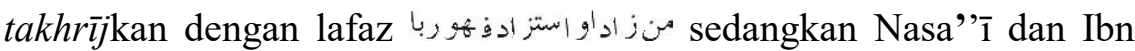

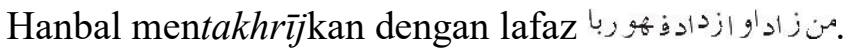

Dengan mencermati lafaz-lafaz hadīs yang penulis sebutkan di atas, sekalipun terdapat sisipan ataupun tambahan lafaz hadīs, namun kedudukannya untuk memperjelas maksud yang dituju oleh hadīs. Oleh karena itu, dengan membandingkan secara cermat lafaz-lafaz yang terdapat pada masing-masing hadīs di atas, maka dapat disimpulkan bahwa setiap hadīs yang ditakhrījkan itu memiliki makna yang sama yang terkandung dengan hadīs yang lainnya. Ada pun per-

bedaan itu tidak berarti memiliki kandungan yang tidak sama, namun posisi hadīs itu untuk menguatkan hadīs yang lainnya.

Para ulama consensus menyebutkan dalam hadīs larangan muamalah riba itu hanya beberapa jumlahnya namun dapat dianalogikan ke- pada semua jenis produk sesuai dengan perkembangan peradaban ma- nusia, namun tentu dengan syarat bahwa benda yang dianalogikan itu mempunyai illat yang sama dengan salah satu dari macam benda yang disebutkan dalam hadīs larangan riba itu.

\section{B. Pendapat para ulama terhadap hadīs-hadīs riba}

Ulama kontemporer yang diwakili Ahmad Musthāfa al-Marāgi misalnya, dalam tafsirnya menyatakan bahwa dikenal dua bentuk riba' dalam hukum Islam. Yaitu, ribā al-qarūd yang berhubungan dengan

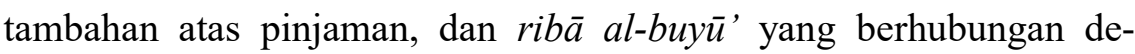
ngan tambahan atas jual-beli. Riba' al-buyü' ada dua bentuk yakni riba' al-fadhl dan riba' al-nasi'ah. ${ }^{35}$ Ibnu Hajar lebih tegas mengatakan bahwa riba adalah semua bentuk jual beli yang hukumnya haram. ${ }^{36}$ Dalam Kifāyah al-Akhyar karya Taqiy al-Dīn dijelaskan bahwa riba' al-fadl, meliputi penukaran secara bersamaan dari barang yang sama yang memiliki kualitas atau kuantitas yang tidak sama. Sedangkan riba' nasi'ah, meliputi pertukaran secara tidak bersamaan dalam pelak-

35 Ahmad Musthāfa al-Marāgiy, Tafsīr al-Marāgiy, Juz I, (Mesir: Musthāfa alBābi al-Halabi wa Awlāduh, 1979), h. 211.

36 Abdul Wahab Khalllaf, Ilmu Ushul Fiqhi, (Mesir: Maktabah al-Dakwah alIslamīyah Syu'bah al-Azhar, 1367H/1957M), h. 217. 
sanaan, keduanya dilarang. ${ }^{37}$

Mengenai riba yang tidak berlifat ganda, atau riba' al-fadhl, kalangan ulama memahaminya juga secara berbeda-beda. Ada yang mengharamkan, dan ada pula yang tidak. ${ }^{38}$ Tetapi kebanyakan ulama kontemporer tidak mengharamkan riba' al-fadhl dengan alasan maslahat atau hajat. Yang diharamkan adalah riba yang berlipat ganda. ${ }^{39}$

Muhammad Abduh dan Mahmud Syaltut misalnya, secara jelas menegaskan bahwa yang haram hanya riba yang berlipat ganda. Ulama kontemporer lain yang diwakili Thaba'tabai dalam tafsirnya Al-Mizān menyatakan bahwa riba terdiri atas dua, yaitu riba' qardhiy yang berkaitan dengan pinjaman, dan riba' mu'āmalah yang berkaitan dengan transaksi. Yang disebutkan pertama adalah seseorang meminjam sejumlah barang atau uang kepada orang lain, kemudian ia mengembalikannya dengan tambahan. Sedangkan yang disebut terakhir adalah kasusnya bukan pinjaman, melainkan transaksi yang berlaku dalam pertukaran antarjenis barang yang sama, misalnya gandum kualitas tinggi dengan gandum kualitas rendah. ${ }^{40}$

Sekelompok fuqaha berpegang pada zahir hadīs ini, bahwa barang riba itu terbatas pada enam jenis yang tersebut dalam hadīs saja. Pendapat ini dipegang oleh golongan Zahiriyyah, Qatadah, Thawus, Usman al-Batti, dan Ibn Aqil al-Hanbali. ${ }^{41}$ Implikasi dari pendapat ini ialah bahwa selain jenis lainnya tidaklah dikategorikan riba. Sedangkan kelompok yang terdiri dari Ammar, Abu Hanifah, dan Ahmad bin Hanbal, dalam suatu riwayat memandang bahwa segala sesuatu yang dijual dengan memakai takaran atau timbangan dapat

37 Taqiy al-Dīn Abī Bakar bin Muhammad al-Husainiy, al-Hushniy alDimasyqy al-Syafī'iy, Kifāyah al-Akhyār fì Hal Gāāyah al-Ikhtishāa, juz I, (t.t.: Syirkah al-Ma'ārif li al-Thba' wa al-nasyr, t.th), h. 247.

38 Sayyid Sābiq, Fiqh al-Sunnah, jilid III, (Cet. VIII; Bairūt: Dār al-Kutub al'Arabiy, 1987), h. 113-114. Muhammad al-Jazīriy, Kitāb Fiqh 'Alā Mazāhib al-Arba'ah, Juz II, (Beirut: Dār al-Fikr, 1982), h. 246.

39 H. Chuzaimah T. Yanggo dan H.A. Hafiz Anshary (ed), Problematika Hukum Islam Kontemporer, (Cet. I; Jakarta: LSIK, 1999), h. 39 dan 41.

40 'Allāmah Muhammad Husayn Thabāthabāiy, Al-Mīzān fì Tafsīr al-Qur'ān. Jilid II, (Cet. II; Teheran: Dār al-Kutub al-'Ilmiyah, 1971), h. 293-294.

41 Wahbah Zuhailiy al-Fiqh al-Islamiyah Wa Adillatuh, Juz IV (Suriah: Dār alFikr, 1989), h. h. 636. 
dikategorikan riba. ${ }^{42}$ Sedangkan menurut Al-Syafii dan Ahmad dalam suatu riwayat berpendapat bahwa riba itu memasuki emas, perak dan tiap-tiap makanan dan minuman yang dijual dengan memakai takaran dan timbangan. Sedangkan mazhab Maliki memandang keha- raman riba' fadhl itu atas makanan yang merupakan makanan pokok yaitu makanan yang biasanya menguatkan tubuh. ${ }^{43}$ Taqiyuddin berpendapat, bahwa riba tidak akan terjadi di dalam praktek jual beli dan salam, pada selain enam jenis barang yang disebutkan dalam ha- dīs. Sedangkan riba dalam praktek gard bisa terjadi pada segala jenis. Karena selain keenam jenis barang tersebut tidak terdapat satu dalil pun yang mengharamkannya, sehingga praktek riba tidak terjadi pada yang lain. ${ }^{44}$

Ulama kontemporer Syaikh Mahmud Syaltut menyatakan, saat ini uang adalah kebutuhan pokok, uang yang diserahkan (ditabung) oleh penyimpan (di bank) bukan merupakan utang. Ia memahami bahwa jasa tabungan yang berupa pemutaran uang dalam bentuk dagang jarang terjadi kerugian dalam perdagangan tersebut. $^{45}$ Da- lam menerangkan tabungan, ia agaknya menitikberatkan perhatian pada lahirnya keuntungan pemberian dan penerimaan simpanan, kendati akadnya terperangkap dalam rumusan riba dalam bentuk riba'nasi'ah.

Berkenaan dengan hukum riba, dapat dibagi atas dua kelompok. Kelompok pertama mengharamkan riba, besar atau kecil. Kelompok kedua mengharamkan riba yang berlipat ganda. Tambahan yang ke- cil, menurut kelompok yang kedua, tidak termasuk riba yang diha- ramkan.

Jenis riba seperti disebutkan di atas muncul apabila peminjam harta orang lain, apa pun bentuknya, dibebani oleh si pemberi pinjaman untuk membayar suatu tambahan tertentu di samping pokok pinjaman pada saat pelunasan. Jika tambahan itu ditetapkan sebelumnya pada awal transaksi sebagai suatu jumlah tertentu, dengan cara bagaimanapun

42 Badruddin Abi Mahmud Muhammad bin Ahmad al-A'ini, Umdat al-Qariy Syarh Shahih Bukhariy, Juz XI, (Beirut: Dar al-Fikr, t.th.), h. 252.

43 Badaruddin, ibid.

44 Taqiyuddin al-Nabhani, op. cit., h. 284-285.

45 Mahmud Syaltut, Al-Fatawa, (Cet. III; Mesir: Dar al-Qalam, 1976), h. 251. 
pertambahan ini terjadi, maka pinjaman itu menjadi pinjaman riba. Pelarangan diperluas kesemua bentuk pinjaman dan utang yang mem- berikan tambahan kepada si kreditur.

Berkaitan dengan uraian di atas, rumusan riba' nasi'ah yang dikemukakan ulama pada dasarnya mempunyai tiga unsur. Pertama, terjadi karena pemimjaman dalam waktu tertentu. Kedua, kepada pihak yang berutang berkewajiban memberi tambahan kepada pihak pemberi utang ketika mengangsur atau melunasi, sesuai perjanjian. Ketiga, obyek peminjaman berupa benda riba.

Pada sisi lain dalam transaksi jual beli dalam bentuk transaksi finan- sial yang berlangsung di dunia global dengan perekonomian saat ini, bentuk jual beli banyak ditemui pada bank-bank asing, sebut saja misalnya jual beli dengan mata uang rupiah dengan dolar Amerika Serikat atau dengan mata uang asing lainnya. Semuanya ini mubah, karena uang tersebut menjadi jelas karena adanya pernyataan dalam suatu transaksi, sehingga pemilihan atas bendanya bisa ditetapkan. Ak- tivitas tersebut adalah aktivitas sharf, ${ }^{46}$ juga sering diistilahkan dengan valuta asing. ${ }^{47}$

Praktek sharf tersebut bisa terjadi dalam uang seperti halnya dalam pertukaran emas dan perak. Karena sifat emas dan perak bisa berlaku untuk semua jenis barang, sama-sama dengan mata uang. ${ }^{48}$ Demikian pula bila emas dijual dengan emas atau perak dengan perak baik antara dua jenis dinar, atau cincin, atau batangan, maka harus - untuk tidak mengatakan wajib - sama-sama timbangannya, barangnya sama-sama ada, sama-sama kontan, dan tidak boleh melebihkan atas yang lain.

Dalam tulisan ini penulis sangat sependapat dengan apa yang dikatakan oleh al-Sabunī dalam menerangkan persoalan riba. Beliau menegaskan, ada beberapa hal yang menyebabkan riba diharamkan di antaranya ialah (1) merusak jiwa; (2) merusak persatuan dan kesatuan,

46 Sharf menurut bahasa berarti penambahan. Sedangkan menurut syara', sharf adalah transaksi jual beli mata uang yang sejenis atau tidak sejenis, atau menjual emas dengan emas, perak dengan perak baik yang berbentuk perhiasan atau batangan. Wahbah al-Zuhaili, op. cit., h. 636 .

47 Ensiklopedi Hukum Islam, jilid V (Jakarta: PT. Ichtiar Baru Van Hoeve, 1996), h. 1610.

48 Taqiyuddin al-Nabbani, Al-Nidham al-I'tisadiy Fi al-Islamiy, op.cit., h. 283. 
dan (3) merusak sendi-sendi kemasyarakatan ${ }^{49}$ yang berpengaruh ter- hadap keadaan hidup umat, baik dari ekonomi, sosial, budaya mau- pun aspek lainnya. Al-Quran dan hadīs hanya menjelaskan secara global saja, sedangkan langkah-langkah pelaksanaan diserahkan pada kemampuan melakukan ijtihad yang sesuai dengan waktu dan tempat yang dihadapi oleh umat.

\section{Kesimpulan}

Berdasarkan uraian di atas, dapat disimpulkan bahwa ada dua jenis riba, yakni riba' nasi'ah dan fadhl. Riba' nasi'ah berhubungan dengan tambahan atas pinjaman, dan merupakan pertambahan bersyarat yang diperoleh orang yang mengutangkan dari orang yang berutang lantaran penangguhan. Sedangkan riba' fadhl adalah riba dalam bentuk penukaran uang dengan uang atau barang komsumsi dengan barang komsumsi dengan tambahan. Jadi riba' fadhl adalah jenis riba yang penukaran suatu benda (komuditas) yang sama namun kualitas dan kuantitasnya berbeda. Maka pada akhirnya ulama memandang bahwa hukum asal riba adalah haram, tidak haram melainkan mubah dan karena itu implikasi kajian ini ialah menyatakan bahwa sangat penting bagi umat Islam untuk mengikuti keyakinan dalam hatinya mana haram dan mengikuti keyakinan dalam hatinya mana tidak haram.

\section{Wallahu 'alam.}

49 Al-Sabunī, op.cit., h. 394. 


\section{DAFTAR PUSTAKA}

Ahmad, Arifuddin, Paradigma Baru Memahami Hadis Nabi, (Cet. I: Jakarta: Renaisan, 2005).

Al-A'ini, Badruddin Abi Mahmud Muhammad bin Ahmad, Umdat alQariy Syarh Shahih Bukhariy, Juz XI (Beirut: Dar al-Fikr, t.th.).

Al-Bukhāri, Abū 'Abdullāh ibn al-Mughīrah al-Bardzibat, Shahīh Bukhāri dalam CD. Rom al-Hadīś al-Syarīfah, Kitāb al-Buyū', hadis ke-2031.

Al-Halawiy, Ahmad Zakariyah al-Qanad, Al-Muwaththa' wa jazu alMasalik (cet. III; t.tp. Dar al-Fikr:, 1980).

Al-Hanafi, Al-Sayȳ̄d Syarīf bin Muhammad bin Ali al-Sayyīd al-Zain Abu Al-Hasan al-Husaini al-Jurjani, al-Ta'rifat, (Mesir: Mustafa al-Babi’ al-Halabi’ wa Syurakahu 1938).

Al-Jastan̄̄, Imam al-Hafiz Abu Daud Sulaiman al-Asy-at bin Ishaq alAzdī, Sunan Abu' Da'ud, Jilid III (t.tp: Al-Maktabah al-Ba'bī alHalabī, 1381 H/1952M).

Al-Jazīriy, Muhammad, Kitāb Fiqh 'Alā Mazāhib al-Arba'ah, Juz II, (Bairut: Dār al-Fikr, 1982).

Al-Jurjāni, al-Ta'rīfāt, (Mesir: Musthāfa al-Bābi al-Halabi, 1978).

Al-Khallaf, Abdul Wahab, Ilmu Ushul al-Fiqh, (Jakarta: Majelis al'Ala Indonesia li al-Da'wah al-Islamiyah, 1972).

Al-Mahdi, Abû Muhammad, Urq Takhrij Hadis Rasulullah Saw, diterje- mahkan oleh H.S.Aqil Husain Munawar dengan judul Metode Takhrij Hadis, (Semarang: Dina Utama, t.th).

Al-Marāgiy, Ahmad Musthāfa, Tafsīr al-Marāgiy, Juz I, (Mesir: Musthāfa al-Bābi al-Halabi wa Awlāduh, 1979).

Al-Nabbani, Taqiyuddin, Al-Nidham al-I'tisadiy Fi al-Islamiy diterjemah- kan oleh Muh. Magfur dengan judul Membangun Sistem Ekonomi Alternatif (Surabaya: Risalah Gusti, 1996).

Al-Naisaburī, Abu Husain Muslim bin al-Hajjaj, SahihMuslim, Jilid III, (t.tp: Mustafa al-Ba'bī al-Halabī, t.th.).

Al-Suyūtiy, Jalāl al-Dīn Abd. al-Rahnmān, Lubāb al-Nuqūl fì Asbāb alNuzūl diterjemahkan oleh K. H. Q. Shaleh, et. al, Asbabun Nuzul; 
Latar Belakang Historis Turunnya Ayat-ayat al-Quran, (Bandung: Diponegoro, 1975).

Al-Syafî̀'iy,Taqiy al-Dīn Abī Bakar bin Muhammad al-Husainiy, alHushniy al-Dimasyqy, Kifāyah al-Akhyār fì Hal Gāāyah al-Ikhtishā, Juz I, (t.t.: Syirkah al-Ma'ārif li al-Thba' wa al-nasyr, t.th).

Amin, Muhammadiyah, Menembus Laitul Qadar Perdebatan Interpertasi Hadis Tekstual dan Kontekstual, (Cet. I; Makassar: Melania Press, 2004).

Departemen Pendidikan dan Kebudayaan R.I., Kamus Besar Bahasa Indo- nesia, (Cet. III; Jakarta: Balai Pustaka, 1994).

Ensiklopedi Hukum Islam, Jilid V, (Jakarta: PT. Ichtiar Baru Van Hoeve, 1996).

Fa'ris Zakariyah, Abu Husain bin, Mu'jam Maqayis al-Lugah, (Cet.VII; [t.tp.]: al-Ba'bī al-Halabī, [t.th.]).

Hanbal, Ahmad bin, Musnad Ahmad bin Hanbal, Juz II, (Bayrut: Dar al-Fikr, t.th.).

Ismail, M. Syuhudi, Dampak Penyebaran Hadīs Palsu dan Manfaat Penge- tahuan: Sebab Hajat Turun dan Sebab Hadīs Terjadi Bagi Muballig dan Pendidik, (Ujung Pandang: Berkah, 1989).

.........., Kaedah Kesahehan Sanad hadīs (Telaah) Kritis dan Tinjauan de- ngan Pendekatan Ilmu Sejarah), (Jakarta: Bulan Bintang, 1988).

..........., Metodologi Penelitian Hadīs Nabi, (Jakarta: Bulan Bintang 1992).

John Wensinck, Arnold, Concordance Et Indices De La Tradition Musul- manne, diterjemahkan oleh Mu¥ammad Fuad Abd al-Baqiy dengan judul Al-Mu'jam al-Mufahras Li Alfasi al-hadis alNabawiy, Juz II, (Leiden: E.J.Brill, 1936).

Khalllaf,Abdul Wahab, Ilmu Ushul Fiqhi, (Mesir: Maktabah alDakwah al-Islamīyah Syu'bah al-Azhar, 1367H/1957M).

Munawwir, A.W., Kamus Al-Munawwair Arab Indonesia Lengkap, (Cet. II; Surabaya: Pustaka Progressif, 2002).

Nasution, Harun, et. al., Ensiklopedi Islam Indonesia, (Jakarta: Djambatan, 1992).

Sābiq, Sayyid, Fiqh al-Sunnah, Jilid III, (Cet. VIII; Beirūt: Dār al-Kutub 
al-'Arabiy, 1987).

Shihab, M.Quraish, Membumikan al-Quran: Fungsi dan Peran Wahyu dalam Kehidupan Masyarakat, (Cet. XII; Bandung: Mizan, 1996).

Syaibah, Abd Rahman bin, Sunan al-Nasa'--̄, Juz VII (Mesir: Mustafa al-Ba'bī al-Halabī, t.th.).

Syaltut, Mahmud, Al-Fatawa, (Cet. III; Mesir: Dar al-Qalam, 1976).

Yanggo H. Chuzaimah T., dan Anshary, H.A. Hafiz, (ed), Problematika Hukum Islam Kontemporer, (Jakarta: LSIK, 1999).

Thabāthabāiy, 'Allāmah Muhammad Husayn, Al-Mīzān fì Tafsīr alQur'ān. Jilid II, (Cet. II; Teheran: Dār al-Kutub al-'Ilmiyah, 1971).

Wensick, A.J., dan Mensing, J.P., Mu'jam Mufahras lī Alfa'z al-Hadīs al-Nabawī, Juz II, (London: A.Briel Leiden, 1943).

Yanggo, H. Chuzaimah T., dan Anshary, H.A. Hafiz (ed), Problematika Hukum Islam Kontemporer, (Cet. I; Jakarta: LSIK, 1999).

Yasir al- Qazwinī, Muhammad bin, Sunan Ibn Majah, Juz II (Bayrut: Dar al-Fikr, t.th).

Zakariyah, Abū Hasan Ibn Fāris Ibn, Mu'jam Maqāyis fi al-Lughah,

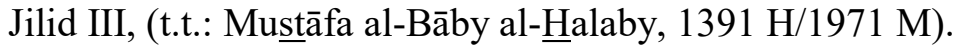

Zuhaili, Wahbah, al-Fiqh al-Islamiyah Wa Adillatuh, Juz IV, (Suriah: Dar al-Fikr, 1989).

Zuhailiy, Wahbah, al-Figh al-Islamiyah Wa Adillatuh, Juz IV, (Suriah: Dā al-Fikr, 1989). 


\section{LAMPIRAN-LAMPIRAN}

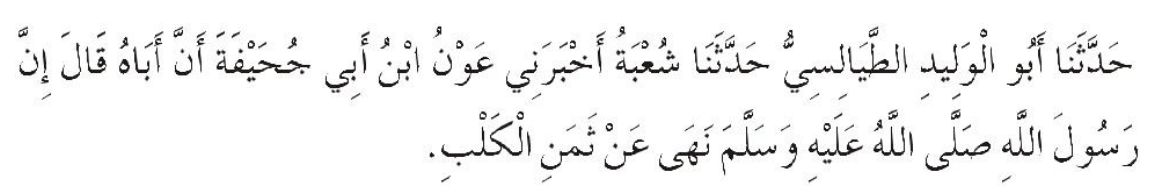

Abu Daud. 3022 satu kali disebut. Telah menceritakan kepada kami Abu Al Walid Ath Thayalisi telah menceritakan kepada kami Syu'bah telah mengabarkan kepadaku 'Aun bin Abu Juhaifah bahwa Ayahnya berkata, "Sesungguhnya Rasulullah shallallahu 'alaihi wasallam melarang dari hasil penjualan anjing."



Ahmad. 18019. 7.1. kali dengan persi yang berbeda. Telah menceritakan kepada kami Muhammad bin Ja'far Telah menceritakan kepada kami Syu'bah dari 'Aun bin Abu Juhaifah dari bapaknya bahwa ia membeli seorang budak yang berprofesi tukang bekam. Lalu ia menyuruh untuk mengambil alat bekamnya kemudian memecahkannya. Maka saya pun bertanya kepada, "Apakah kamu memecahkannya?" Dia menjawab, "Ya, sesungguhnya Rasulullah shallallahu 'alaihi wasallam melarang Tsaman Ad-Dam (bayaran dari hasil bekam), hasil penjualan anjing, pendapatan wanita pelacur. Dan beliau melaknat orang yang mentato dan yang minta ditato serta melaknati pemakan riba dan orang yang memberi makan dari hasil riba, kemudian beliau juga melaknat tukang gambar." 




Ahmad. 18007. 2. Telah menceritakan kepada kami 'Affan Telah menceritakan kepada kami Syu'bah telah mengabarkan kepadaku Aun bin Abu Juhaifah ia berkata; Saya melihat bapakku membeli seorang budak yang bekerja sebagai tukang bekam. Kemudian ia memerintahkannya untuk mengambil alat-alat bekam miliknya lalu alat-alat bekam itu pun dipecahkan. Maka menanyakan hal itu kepadanya, dan ia pun menjawab, "Rasulullah shallallahu 'alaihi wasallam melarang, Tsaman Ad Dam (bayaran dari hasil bekam), hasil penjualan anjing, pendapatan perempuan pelacur. Dan beliau melaknat orang yang menato dan yang minta ditato serta melaknati pemakan riba dan orang yang memberi makan dari hasil riba, kemudian beliau juga melaknat tukang gambar."

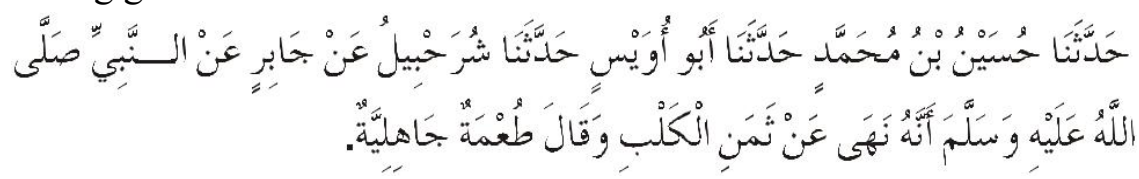

Ahmad. 14274. 3.Telah bercerita kepada kami Husain bin $\mathrm{Mu}$ - hammad telah bercerita kepada kami Abu 'Uwais telah bercerita ke- pada kami Syurohbil dari Jabir dari Nabi shallallahu'alaihi wasallam sesungguhnya beliau melarang hasil penjualan anjing dan berkata: itu makanan orang jahiliyah.

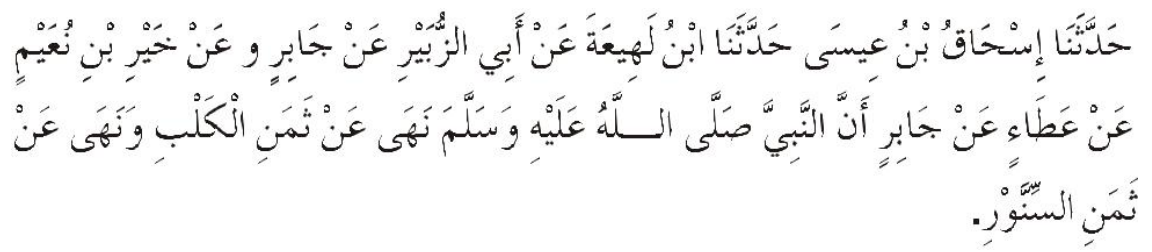

Amad. 14125 4.Telah menceritakan kepada kami Ishaq bin 'Isa telah menceritakan kepada kami Ibnu Lahi'ah dari Abu Az-Zubair dari Jabir dan dari Khair bin Nua'im dari 'Atha' dari Jabir, Nabi 
Shallallahu'alaihi wasallam melarang hasil penjualan anjing dan (Ra- sulullah shallallahu 'alaihi wasallam) juga melarang hasil penjualan kucing.

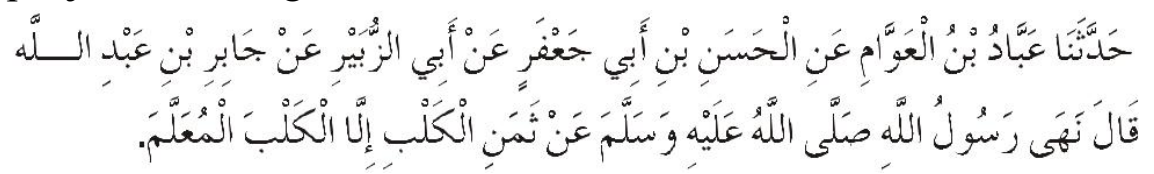

Ahmad. 13891. 5.Telah bercerita kepada kami 'Abbad bin al'Awwam dari Al-Hasan bin Abu Ja'far dari Abu Az-Zubair dari Jabir bin Abdullah berkata; Rasulullah shallallahu 'alaihi wasallam mela- rang hasil penjualan anjing kecuali anjing yang dididik untuk tugas khusus.



Ahmad. 3013. 6. Telah menceritakan kepada kami Zakariya bin Adi telah menceritakan kepada kami Ubaidullah dari Abdul Karim dari Qais bin Habtar At-Tamimi dari Ibnu Abbas dari Rasulullah shallallahu 'alaihi wasallam bahwa beliau melarang harga (hasil pen- jualan) khamar, upah melacur, dan hasil penjualan anjing. Ia berkata; Apabila ada yang datang kepadamu meminta hasil penjualan anjing maka penuhilah tangannya dengan tanah.

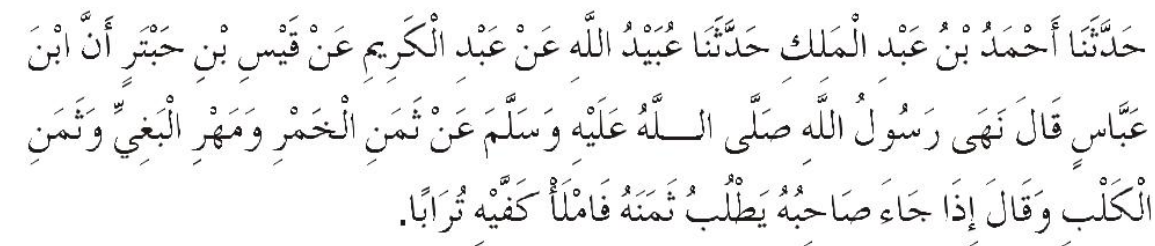

Ahmad. 2495.7 Telah menceritakan kepada kami Ahmad bin Abdul Malik telah menceritakan kepada kami Ubaidullah dari $\mathrm{Ab}$ - dul Karim dari Qais bin Habtar bahwa Ibnu Abbas berkata; "Ra- sulullah shallallahu 'alaihi wasallam melarang (menerima) harga (ha- sil penjualan) khamar, upah pelacuran dan harga anjing. Dan beliau bersabda: "Apabila pemiliknya datang meminta harga, maka penuhi- lah tangannya dengan tanah." 




Bukhari. 2084.5.1 Telah menceritakan kepada kami Hajjaj bin Minhal telah menceritakan kepada kami Syu'bah berkata, telah mengabarkan kepada saya 'Aun bin Abu Juhaifah berkata; Aku meli- hat bapakku membeli tukang bekam lalu memerintahkan untuk meng- hancurkan alat-alat bekamnya. Kemudian aku tanyakan masalah itu. Lalu bapakku berkata: "Rasulullah shallallahu 'alaihi wasallam telah melarang harga (uang hasil jual beli) darah, anjing, memeras budak perempuan dan melarang orang yang membuat tato dan yang minta ditato dan pemakan riba dan yang meminjamkan riba, serta melaknat pembuat patung".

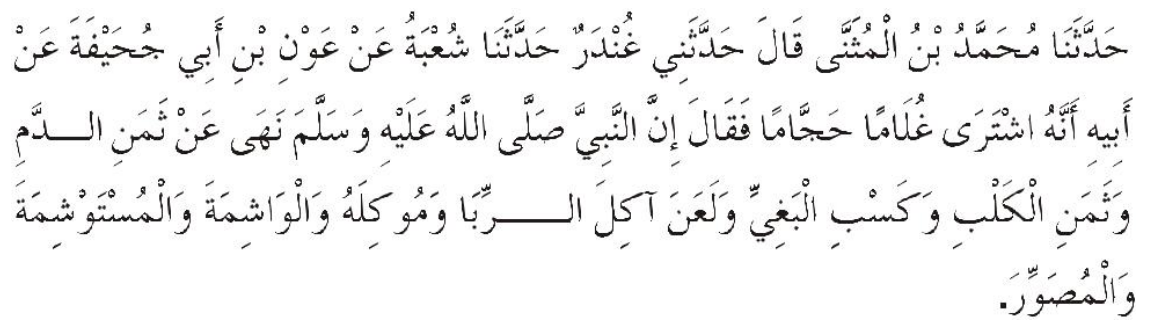

Bukhari. 5505. 2. Telah menceritakan kepada kami Muhammad bin Al Mutsanna dia berkata; telah menceritakan kepadaku Ghundar telah menceritakan kepada kami Syu'bah dari 'Aun bin Abu Juhaifah dari ayahnya bahwa dia pernah membeli seorang budak tukang be- kam, lalu dia berkata; "Sesungguhnya Nabi shallallahu 'alaihi wasallam melarang hasil penjualan darah, hasil penjualan anjing dan hasil pe- lacuran, beliau juga melaknat pemakan riba dan yang memberi ma- kan, orang yang menato dan yang minta ditato serta melaknat peng- gambar." 


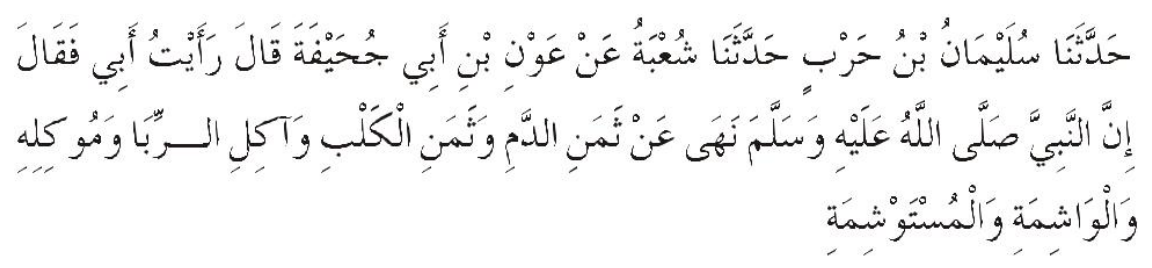

Bukhari. 5489.3 Telah menceritakan kepada kami Sulaiman bin Harb telah menceritakan kepada kami Syu'bah dari 'Aun bin Abu Juhaifah dia berkata; aku pernah melihat ayahku berkata; sesungguhnya Nabi shallallahu 'alaihi wasallam melarang hasil (menjual) darah dan hasil penjualan anjing, memakan riba dan yang memberi makan dan yang mentato dan yang meminta ditato."

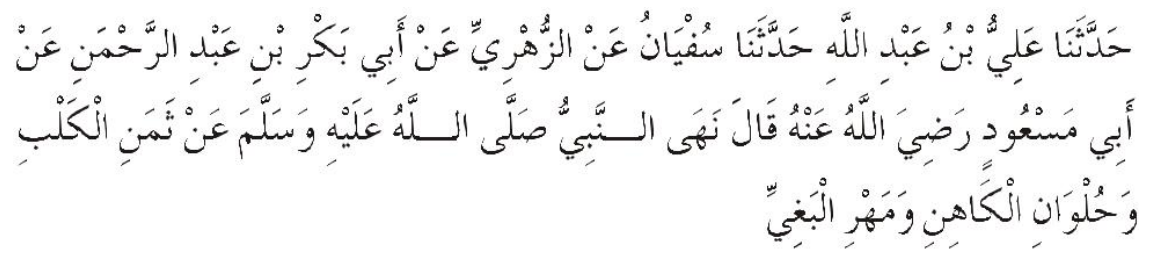

Bukhari.4927 4. Telah menceritakan kepada kami Ali bin Abdullah Telah menceritakan kepada kami Sufyan dari Az Zuhri dari Abu Bakr bin Abdurrahman dari Abu Mas'ud radliallahu 'anhu, ia berkata; Nabi shallallahu 'alaihi wasallam melarang untuk memakan hasil keuntungan dari anjing, dukun, dan pelacur.

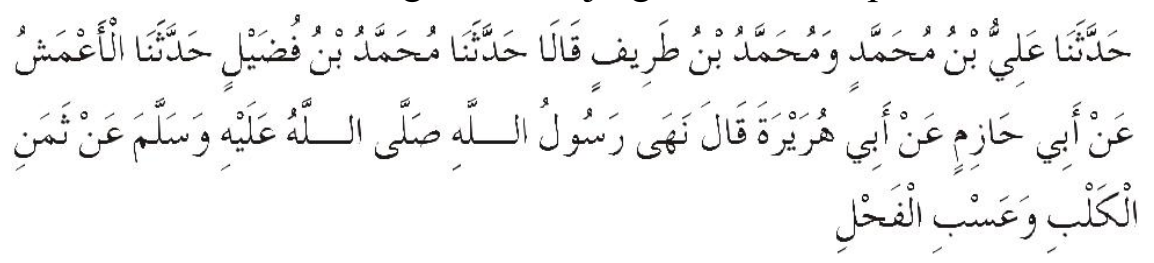

Ibnu Majah. 2151. Telah menceritakan kepada kami Ali bin Muhammad dan Muhammad bin Tharif keduanya berkata; telah menceritakan kepada kami Muhammad bin Fudlail berkata, telah menceritakan kepada kami al-A'masy dari Abu Hazim dari Abu Hurairah ia berkata, "Rasulullah shallallahu "alaihi wasallam melarang makan dari hasil penjualan anjing dan hasi zina." 


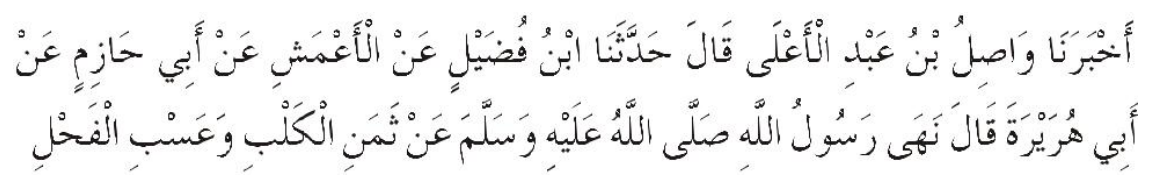

Annasai'. 4596. Telah mengabarkan kepada kami Washil bin Abdul A'la, ia berkata; telah menceritakan kepada kami Ibnu Fudhail dari al-A'masy dari Abu Hazim dari Abu Hurairah ia berkata; Rasulullah shallallahu 'alaihi wasallam melarang dari jual beli anjing dan penyewaan pejantan.

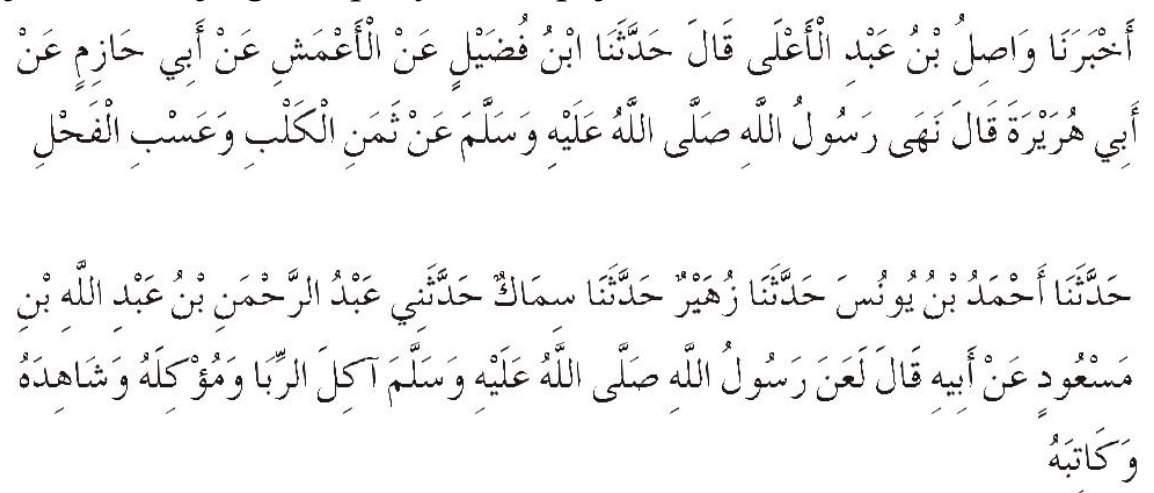

(ABUDAUD - 2895) : Telah menceritakan kepada kami Ahmad bin Yunus, telah menceritakan kepada kami Zuhair, telah menceritakan kepada kami Simak, telah menceritakan kepadaku Abdurrahman bin Abdullah bin Mas'ud, dari ayahnya, ia berkata; Rasulullah shallallahu 'alaihi wasallam melaknat orang yang makan riba, orang yang mem- beri makan riba, saksinya dan penulisnya. Abu Daud Kitab Jual Beli, bab; Orang yang makan riba dan orang yang memberikannya nomor.

Hadīs 2895.

Selanjutnya hadīs yang berasal dari Ibn Mas'ud yang dikeluarkan pula oleh Abu Daud:

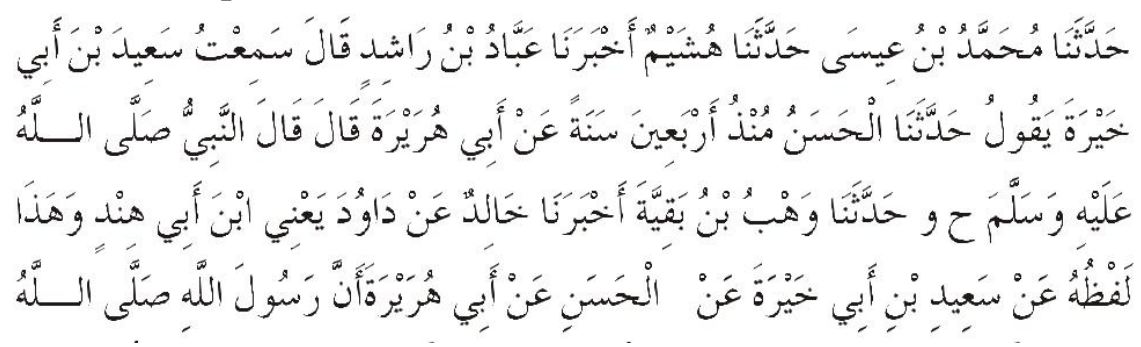




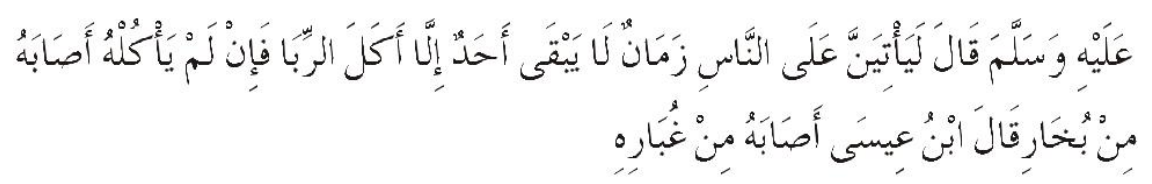

Telah menceritakan kepada kami Muhammad bin Isa, telah menceritakan kepada kami Husyaim, telah mengabarkan kepada kami 'Abbad bin Rasyid, ia berkata; saya mendengar Sa'id bin Abu Khairah ia berkata; telah menceritakan kepada kami al-Hasan sejak empat puluh tahun, dari Abu Hurairah, ia berkata; Nabi shallallahu 'alaihi wasallam bersabda: Dan telah diriwayatkan dari jalur yang lain. Dan telah menceritakan kepada kami Wahb bin Baqiyyah, telah mengabarkan kepada kami Khalid, dari Daud bin Abu Hindun, dan ini adalah lafazhnya. Dari Sa'id bin Abu Khairah, dari al-Hasan dari Abu Hurairah bahwa Rasulullah shallallahu 'alaihi wasallam bersabda: "Sungguh akan datang kepada manusia suatu zaman di mana tak ada seorang pun melainkan ia akan makan riba, jika tidak memakannya maka ia terkena sebagian dari uapnya." Ibnu Isa berkata; terkena sebagian dari debunya. 